\title{
Essayet som genre
}

\author{
Per DAHL
}

Det følgende er ikke noget essay, men et forsøg på at bestemme centrale genretræk ved essayet, selvom det er let at finde eksempler, der underminerer ethvert tilløb til definition af så løs og flygtig en genre. Men i ordets oprindelige mening bliver der dog tale om et forsøg eller tilløb. Ikke det store spring, snarere hvad Per Højholt engang kaldte ,opspring fra nulhuller“.

Det er altså hensigten at søge de konstanter, man vil kunne genkende $\mathbf{i}$ forskellige tiders essays (også $\mathbf{i}$ dem, der er trykt i dette nummer af Passage), og som udgør det usynlige partitur, mange essayister i bevidst og ubevidst genoptagelse og fornyelse improviserer over.

Men her kommer forst en germansk definition, som er systematisk og nyttig - og langt fra essayistisk. Det drejer sig om opslaget „Essay“ i Gero von Wilperts kendte Sachwörterbuch der Literatur. I den lange, tyske hypotakse har hver eneste bestemmelse sin rette, tilmålte plads, men sætningsforløbets velordnede systematik er ikke desto mindre så uoverskuelig, at jeg har oversat artiklen til dansk og fremhævet de fire kendetegn:

Essay (engelsk, fransk essai $=$ forsøg).

Kortere afhandling $\mathrm{i}$ en lettilgængelig, dog såvel kunstnerisk som dannelsesmæssigt fordringsfuld, åndrig og æstetisk tilfredsstillende form, om et videnskabeligt emne eller om et aktuelt spørgsmål angående det åndelige, kulturelle eller sociale liv og lignende, kendetegnet [I] ved en bevidst subjektivitet $i$ opfattelsen, som - selv på trods af punktvis forældede videnskabelige forudsætninger - giver essayet blivende værdi som åndeligt vidnesbyrd om dets forfatter, [2] ved bevidst afkald på en systematisk og udtømmende analyse af sagforhold til fordel for en mosaikagtigt åben tankerække, som - næsten vilkårligt og springsk-associativt - belyser temaet, søger at formidle den essentielle individuelle erkendelse, tilstræber en rekonstruktion af den personlige oplevelse og ser temaet i store sammenhænge, [3] ved udsagnets foreløbighed - trods al aforistisk træfsikkerhed i det enkelte - og ved det uforpligtende i de fremlagte, mulige sammenhænge, som ikke tillader nogen som helst generalisering og [4] endelig ved suveræniteten $i$ håndteringen af stoffet. Essayet gælder derfor som en åben form for fragmentarisk sandhed, som en svævende tilstand mellem viden og tvivl, og adskiller sig fra den strengt objektive, videnskabeligt-saglige afhandling ved sin subjektive formulering og fra den mere overfladiske journalistiske føljeton ved sit intellektuelle niveau og sin stræben efter tidløse indsigter. ${ }^{\mathrm{I}}$

Definitionen indeholder altså fire punkter: Essayet er subjektivt, det er usystematisk, det er provisorisk og det håndterer stoffet suverent. De fire punkter kan måske sammenfattes $\mathrm{i}$ betegnelsen ,intelligent subjektivitet“. Eller sagt på en mere positiv måde end af Wilpert: Essayisten har sét noget, har noget på hjerte og kan give sit indtryk udtryk.

I Wilperts omhyggelige definition er det bemærkelsesværdigt, at de tre første bestemmelser er negative, og at det positive modbillede - det normative sted der defineres fra - er den systematiske og objektive fremstilling: Den akademiske diskurs, som opslaget selv repræsenterer.

At kritisere Wilperts tætte og på mange måder rammende definition er ensbetydende med at afdække eller rekonstruere hans beskrivelsesgrundlag. Det bliver samtidig en beskrivelse af, hvordan essayet bliver til i et opgør med og en bevidst bevægelse væk fra dette grundlag, som altså både negativt og positivt kom til at sætte sig lange spor. I det opbrud kan man finde de centrale træk ved essayet, og her skal fremhæves tre: Essayets rum, essayets jeg og essayets emne. 


\section{Essayets rum}

Essayet har et rum eller skrives $i$ et rum; dvs. hvor vagt det rum end bestemmes, så er der altid en bevidst kommunikations- og receptionssammenhæng at tage i betragtning. Den kan først bestemmes negativt: Essayisten taler ikke på nogens vegne; essayisten står uden for institutioner og magtbastioner; er han lærd, er han i essayets øjeblik uden for auditoriet og udtaler sig ikke som specialist, men er dog heller ikke i en helt anden verden, sådan som det er tilfældet i fiktion. Essayet er en non-fiktional prosa, hvor jeget ikke kommer til orde gennem andre, men taler på egne vegne.

Bag den negative bestemmelse af essayets institutionelle rum ligger der samtidig en gammel, stilmæssig forudsætning: Vi er med ét rykket uden for hele den klassiske retorik og den stil, kancelli- eller kurialstilen, der gennem middelalderen og helt frem til idag bliver benyttet $\mathrm{i}$ pavens romersk-katolske kancelli; den der - som essayisten - taler på egne vegne, taler ikke latin, men bruger folkesproget (modersmålet); han taler ikke ex cathedra, dvs. taler ikke - med hele embedets ufejlbarlige myndighed - ned fra pavestolen eller lærestolen, men med sine egne, sine ligemænd. Essays er ikke skrevet med magtsprogets upersonlige distance; de er ikke belærende. Embedsmanden har forladt sin skranke for at åbne sig for det, der viser sig hinsides skranken.

I „The Superannuated Man“" (fra Last Essays of Elia, I833) har Charles Lamb uhyre præcist gengivet kontoristens let overraskede passage af netop dét skæringspunkt:

Jeg er ikke længere NN, kontorist i firmaet XX. Jeg har trukket mig tilbage. Man kan møde mig i velholdte haver. Man er allerede begyndt at lægge mærke til mit ubekymrede ansigt og min skødesløse holdning, når jeg vandrer omkring uden noget bestemt mål og uden noget bestemt ærinde. Jeg går ikke til og fra, jeg går omkring. Man fortæller mig, at en air cum dignitate, som i lighed med mine andre gode egenskaber så længe har været skjult, er begyndt at træde frem hos mig. Jeg vokser ind i min rolle som gentleman. Når jeg åbner en avis, er det for at se, hvad der spilles på operaen. Opus operatum est. Jeg har gjort alt det, jeg kom til denne verden for at gøre. Jeg har ud- ført det arbejde, som blev mig pålagt. Resten af dagen er min egen. ${ }^{2}$

Essayisten er ikke længere på arbejde eller i embede, og han vinder som menneske en ny værdighed. Mens en anden af periodens engelske essayister, David Henry Thoreau, i I845-47 boede i sin hytte ved Walden Pond i New Hampshire, skrev han foruden sin berømte bog om livet i skoven også essayet „Civil Disobedience“ (offentliggjort I849). Her argumenterer han indædt for individets ret til at undsige en regering, der undertrykker de indfødte indianere og legaliserer slaveriet. „En hæderlig mand“, hedder det, „må trække sig ud af et sådant kompagniskab“. For den liberale tradition, som en del af essayets udvikling er snævert knyttet til, står det frie individ over alt. Borgeren trækker sig fri af myndighedernes omklamring og autoritet, og det hæderlige, civile menneske kommer i grunden bedst til udfoldelse i naturen og dermed også i essayets naturlige stil.

Vil man bestemme essayets rum positivt, sker det ikke ved rummets størrelse, men ved dets karakter: Det er det sted, hvor der kan tales frit, og hvor der er frihed for ytringer; altså den ytringsfrihed man finder i cafeen og salonen. I The Spectator, der I7II-I2 og senere blev udgivet af Joseph Addison og Richard Steele, fremhæver redaktøren i nr. Io, hvordan tidsskriftet „har fảet filosofien ud af (...) biblioteker, skoler og universiteter, så den nu har sin plads i klubber og kaffehuse." Hele den periodiske litteratur i form af magasiner, tidsskrifter og aviser, ligesom senere radioen, har spillet en uoverskueligt stor rolle for udviklingen af essaygenren.

Det er ikke et specielt rum: det er for alle og enhver. Det er en (borgerlig) offentlighed for udveksling af selvstændige iagttagelser, synspunkter og meninger. Det er samtidig et rum med direkte kommunikation: Essayet er den mest direkte og nyttige litterære form. Essayisten taler på egne vegne med tilhørere og læsere, der også reagerer på egne vegne. Tonen kan være overtalende og søge at overbevise, men i andre tilfælde blot lade læseren overhøre den skrivendes meditative samtale med et andet (og bedre) jeg. Derfor er det ikke overraskende, 
at essayets litterære baggrund bl.a. skal søges i de antikke dialoger (Platon), i Plinius', Senecas og Ciceros breve, i Marcus Aurelius' tanker til sig selv og - måske mere overraskende - $\mathrm{i}$ den protestantiske prædiken, hvor præsten fremlægger en fortolkning af evangeliet $\mathrm{i}$ stedet for autoritær, katolsk ortodoksi.

Efter Montaignes stadig lige forbløffende etablering af genren i slutningen af I500-tallet fortsatte I700-tallets tidsskrifter diskussionen af sæd og skik. „Den overordnede hensigt med dette skrift", hed det $\mathrm{i}$ første nummer af The Spectator, ,er at udstille enhver form for kunstfærdighed, at tage fat på enhver form for forstillelse i form af behændighed, forfængelighed og påtagethed og at anbefale almindelig enkelhed i klædedragt, samtale og opførsel.“ Projektet fortsatte $\mathrm{i}$ århundredets saloner og konversation, sådan som den f.eks. afspejles i Kamma Rahbeks private breve og - i det samtidige England - i Maria Edgeworth' Letters for Literary Ladies (I795) en af de fă tidlige, kvindelige essayister. I salonens frie konversation tales der et andet sprog end magtens. Her og i essayet gennemføres en stilfærdig, men effektiv afvikling af retorikken og regelpoetikken til fordel for inspirationens og originalitetens frie løb.

Senere kan man i en dansk sammenhæng og i forbindelse med Henrik Cavlings omlægning af dagbladet Politiken hefte sig ved tilblivelsen af kronikken i 1905. Den fik sin plads den i6. maj I905 nederst på en højreside, hvor den litterære feuilleton indtil da havde stået. Og den plads har kronikken siden holdt. Georg Brandes åbnede med den karakteristiske titel „Den Svageres Ret og Pligt“, som signalerer den social-liberale udvikling af Thoreaus individualisme. I essayet fremhæves dels den selvkritik, som er sporen til individets selvudvikling, dels den sociale forpligtelse til at føle sig ,sam-ansvarlig“ med nationen. 3

Væsentlig for udviklingen af essayets rum er det hørte essay, som i løbet af 30 'erne dukkede op i radioen. Den første, der suverænt udnyttede det nye medium, var den amerikanske præsident, Franklin D. Roosevelt. At høre ham tale til nationen var at se ham. Han udnyttede sit handicap (en lammelse i be- nene), og i stedet for at tale fra det podium i kongressen, hvor han inkarnerede magten, holdt han sine „Fireside Chats“, sine kaminpassiarer, fra sin private lænestol. Ved direkte at henvende sig som menneske, fra stol til stol og fra stue til stue, forklarede han de halvanden million lyttere, hvad The New Deal, der skulle løfte USA ud af verdenskrisen, gik ud på: „Kære venner, jeg vil gerne tale et par minutter med folk i De forenede Stater om bankforretnigner ..."4 Grænsen omkring essayets ikke-autoritære rum bliver her tydelig, fordi Roosevelt fra den politiske side bevæger sig ind over den og udnytter rummet til et øjebliks fortrolighed med borgerne.

I Tyskland er den nærmeste parallel måske Thomas Manns eksiltaler under 2. Verdenskrig (,Deutsche Hörer ..."), i Danmark Karen Blixens radiotaler. „Fra Lægmand til Lægmand“, der handler om vivisektion, blev holdt i radioen den 10. maj 1954; indledningen genfortæller essayets rum på følgende måde:

Ja, Tak fordi De lukkede op for Radioen. Jeg vil takke Dem een Gang til, hvis De vil vente med at lukke for den til jeg er færdig. For jeg taler i Aften ikke for at underholde Dem. Jeg taler om en Sag, som ligger mig paa Hjerte, og som jeg gerne vilde have at ogsaa De skulde tænke over og føle for. Jeg har sagt at jeg talte som Lægmand til Lægmand. Og Ordet Lægmand kan jo opfattes negativt og betyde den Ikke-Sagkyndige, men det kan ogsaa tages positivt og staa for det alment-menneskelige. Det er til dette rent alment-menneskelige, som jeg ved er til Stede til alle Sider omkring mig i Danmark, at jeg taler. 5

\section{Essayets jeg}

Selvom man i det engelske essay, hos den tidlige Francis Bacon og i Addison og Steeles periodiske essays i I700-tallet, kan finde en betydelig narrativisering ved hjælp af en række faste typer, som essayisten kryber ind $\mathrm{i}$, så bliver det essayistiske jeg efter ca. I8oo overvejende et jeg, der taler på egne vegne og undervejs udvikler borgerlig myndighed og selvstændighed under et nationalt tilhørsforhold (The Familiar eller Personal Essay). De midler, der står til rådighed for det ræsonnerende, beskrivende, fortæl- 
lende, analyserende eller kritiserende jeg er først og fremmest egen erfaring og egne oplevelser.

Det gode essay indeholder et maksimum af iagttagelse og deskription; gerne fremlagt $i$ en fortroligt-bekendende form, ofte også selvironisk og selvafslørende, så der ikke opbygges autoritet eller opnås myndighed. Læseren får mange muligheder for indlevelse og identifikation, men fritages ikke fra selv at ræsonnere.

Især hos en ældre essayist som Ludvig Holberg kan man se, hvordan egne iagttagelser suppleres af en omfattende læsning, der ubesværet leverer de eksempler, citater, argumenter, anekdoter og associationer, som kan indmonteres i hans moralske tanker og epistler. ${ }^{6}$

Den form, der kan holde så mange elementer i sit greb, er ikke systematisk. Essayet har ingen fuldstændig eller systematisk komposition, men er atektonisk, skødesløst og åbent bygget op. Det kunne let føre til løst sammenkædede guirlander eller forvirrende mosaikker, og derfor må essayet også rumme en modgående og samlende bevægelse: Det essayistiske Jeg. Det gode essay holder balance mellem deskription og analyse, mellem erfaring og ræsonnement, mellem objektivt og subjektivt. Balancen er tror jeg - snævert knyttet til stilen. Det er den, der er enhedsskabende, og i stilens gennemarbejdede subjektivitet er der - lidt overraskende - et nært slægtskab mellem essayet og lyrikken.

Balancen mellem deskription og analyse medfører, at essayet har et perspektiv eller en retning: Essayisten har et anliggende, og set på baggrund af den form, der netop blev skitseret, består anliggendets retoriske figur i - som det hed hos Wilpert - at se temaet $\mathrm{i}$ store sammenhænge. Med andre ord: At sigte mod noget større ved at tale om noget mindre, som man kender godt, og som læseren også kender til og kan leve med i. Essayet er, som Adorno fremhæver, allegorisk, og den måde, det ofte viser sig på, er i retorikkens pars pro toto-figur, hvor delen må stå for det hele. Forholdet mellem delen og helheden er det sigte eller perspektiv, hvori subjektiviteten eksponerer sig og sætter sig på spil.
Den stil, der karakteriserer essayet, sætter af fra retorikken og kancellistilen, som er et lovsprog og magtsprog.7 Det bruges, når der skal reguleres eller udøves magt i samfundet. Kancellistilen er præcis, entydig og konservativ, fordi den skal fremlægge og fastholde det velafprøvede, det sikre. Dens mest dominerende træk er den periodestil, Wilpert demonstrerede $i$ sin definition af essayet: Det samme emne behandles inden for den samme periode (dvs. samme punktum) og $i$ et logisk og systematisk opbygget over- og underordningsforhold.

Da myndighedernes magtudøvelse skal være saglig og neutral, bliver kancellistilen upersonlig, præget af passivformer og abstrakte udtryk; det er alene sagen, som skal stå frem, ikke den der forvalter den. Stilen får en iøjnefaldende forvægt, fordi fremstillingen først må opridse forhistorie og nærmere omstændigheder, og dernæst benytter en række indskud til at præcisere, nuancere og tage forbehold før der kan træffes endelig og fuld afgørelse.

Følger man - som Paul Diderichsen i I96oerne forsøgte det $\mathrm{i}$ sin aldrig afsluttede prosahistorie udviklingen i fransk og engelsk prosa op igennem I6-I70o-tallet, kan man se, hvordan der her udvikles en essayistisk stil, der i modsætning til kancellistilens retorik er asyndetisk og parataktisk, altså løst sammenknyttende og sidestillende, og samtidig billedrig, fyldt med iøjnefaldende metaforer, som bliver siddende $\mathrm{i}$ erindringen. ${ }^{8}$

\section{Essayets emne}

Etymologisk set er essayet beslægtet med det latinske ord „exagium“, der betyder en undersøgelse, en prøvelse eller vejning af noget (jf. ,eksamen“). I ordet ligger også en tilknytning til ,saggio“, der betyder en del af en større mængde eller helhed, hvorudfra man kan slutte til helhedens beskaffenhed, jf. Adornos bestemmelse af essayet som allegorisk.

I prøvelsen ligger der en karakteristisk dobbelthed: Essayisten undersøger noget, samtidig med at han prøver sig. Ligesom allegorien ikke kan adskilles fra allegoresen og derfor implicerer en fortolker, således er der i essayet en dialektisk sammenhæng mellem objekt og subjekt, som betones til fordel for en begavet subjektivitet, der fremtræder uden auto- 
ritet. „Essayisten“, hævder Per Lange i sit essay „Om Essayets Kunst“, der med fordel kan læses sammen med artiklen i Wilperts leksikon, ,maa nok være lærd, men hvis der er nogen huller i hans Viden - og det er der utvivlsomt - bør han fortrinsvis betragte Verden igennem dem." 9

Essayisten promenerer ikke sin viden, tværtimod er den kun diskret til stede. Han sætter parentes om den, så læseren inviteres til at deltage i ræsonnementet og give sit besyv med. Man skal vove at være dum, som Jens Chr. Grøndahl siger - kvalificeret dum, kunne man tilføje.

Det essayistiske ræsonnement kiler sig ind i og ud af fastslået og etableret viden; det undgår det sikre og samler sin opmærksomhed over for det, vi (endnu) ikke ved noget om eller troede, vi vidste noget om. Det kræver opmærksomhed og refleksion over for alt, hvad der dukker op efterhånden som det vestlige, „moderne“ samfund udvikler sig. Hertil hører det perspektiv, der består $i$ at registrere og udsætte sig for kontraster til denne del af verden. Alt må essayisten registrere, med følsomhed og perspektiv, med erfaringstæthed, skepsis og kritik.

\section{Noter}

I. Sachwörterbuch der Literatur 7. udg. 1989 s. 267-68. Den efterfølgende historiske navneopremsning og de mange henvisninger under opslaget er nyttige, men udeladt her. 2. Essayet er først oversat som „Pensionisten“ af Kurt Sørensen $i$ et privattryk fra 196I, optrykt i K.F. Plesner (red.): Essays (Gyldendals Bibliotek, Verdenslitteratur bd. 38) 1967 , s. I69-77; citatet er essayets slutning. Den engelske tekst findes i Charles Lamb: Complete Works, I897 s. I63-68: „I am no longer $\star \star \star \star \star$, clerk to the Firm of \&c. I am Retired Leisure. I am to be met with in trim gardens. I am already come to be known by my vacant face and careless gesture, perambulating at no fixed pace nor with any settled purpose. I walk about, not to and from. They tell me, a certain cum dignitate air, that has been buried so long with my other good parts, has begun to shoot forth in my person. I grow into gentility perceptibly. When I take up a newspaper, it is to read the state of the opera. Opus operatum est. I havde done all that I came into this world to do. I have worked task-work, and have the rest of the day to myself."

3. Optrykt i Georg Brandes: Samlede Skrifter bd. XVIII, I906.
4. Roosevelt holdt 3I „Fireside Chats“, 8 af dem findes optrykt som en af Penguin Books' jubilæumsbøger, 1995. Jf. iøvrigt Daniel J. Boorstins kapitel 5I (From Oratory to Public Speaking: Fireside Politics) i The Americans vol. 3, 1973.

5. Karen Blixen: Essays, 1965, s. 95. „Fra Lægmand til Lægmand" blev trykt som kronik i Politiken II.I2.5.1954.

6. Jf. FJ. Billeskov Jansen: Holberg som Epigrammatiker og Essayist 1-2, 1938-39. Spec. bd. 2, kap. 2 giver bestemmelser af essaygenren.

7. Om kancellistilen se bl.a. Leif Becker Jensen: „Under henvisning til den af Dem fremsendte skrivelse ...", in: K.P. Pedersen, Grethe Ilsøe og Ditlev Tamm (red.): På given foranledning. En antologi om dansk forvaltningskultur, 1995. I relation til essayet se især Vibeke Sandersen: Essayet - opror og tradition, 1975, og Essayet - filosofi og fiktion, 1977.

8. Først del udkom posthumt som Paul Diderichsen: Dansk Prosahistorie I, 1, 1968; enkelte senere kapitler foreligger i duplikeret form. Der har siden været få opfølgninger af Diderichsens intentioner, der holdt litteratur- og sprogsiden af danskfaget sammen. I Norge har der i de senere år været flere sagprosa-projekter, som har behandlet stiludviklingen, senest Egil Børre Johnsen og Trond Berg Eriksen (red.): Norsk litteraturhistorie. Sakprosa fra 1750 til 1995 (1998).

9. Per Lange: „Om Essayets Kunst“, i essaysamlingen Ved Musikkens Tarskel, 1957; senere optrykt i Samlede Essays, I964 s. I47-52. 